JINOTEP Vol 8 (1) (2021): 146-156

DOI: $10.17977 / \mathrm{um} 031 \mathrm{v} 8 \mathrm{i} 22021 \mathrm{p} 146$

JINOTEP (Jurnal Inovasi Teknologi Pembelajaran)

Kajian dan Riset Dalam Teknologi Pembelajaran

http://journal2.um.ac.id/index.php/jinotep/index

\title{
PENGEMBANGAN SISTEM INFORMASI E-LESSON PLAN PADA PENDIDIKAN ANAK USIA DINI
}

\author{
Leni Gonadi \\ Universitas Negeri Malang - Malang Indonesia
}

\begin{tabular}{l} 
Article History \\
\hline Received: $28-06-2021$ \\
Accepted: $01-07-2021$ \\
Published: $04-07-2021$ \\
Available online: $03-07-$ \\
2021
\end{tabular}

Keywords

E-Lesson plan PAUD,

Perencanaan

Pembelajaran, Pendidik

Anak Usia Dini

\begin{abstract}
Abstrak
Penelitian ini didasari oleh kebutuhan pengelolaan data perencanaan pembelajaran yang dilakukan pendidik berbasis sistem informasi. Penelitian bertujuan mengembangkan sistem informasi e-lesson plan PAUD yang memfasilitasi pendidik dalam pengambilan keputusan perencanaan pembelajaran meliputi kalender pendidikan, rancangan semester, rancangan mingguan dan rancangan harian. Model pengembangan prototipe digunakan dalam proses penelitian ini. Evaluasi formatif oleh pengguna yaitu pendidik anak usia dini, menunjukkan tingkat kesesuaian dengan unsur-unsur perangkat pembelajaran sebesar 83,3\%, dan tingkat kepraktisan sistem sebesar $84,2 \%$. Kepraktisan dan kesesuaian sistem informasi e-lesson plan PAUD berpengaruh sebesar 73,3\% dalam pengelolaan data keputusan perencanaan yang dilakukan oleh pendidik. Hasil penelitian menunjukkan e-lesson plan PAUD praktis dan sesuai digunakan dalam keputusan penyusunan perangkat perencanaan pembelajaran oleh pendidik.
\end{abstract}

\begin{abstract}
The researcher focuses based on the need for data management of learning planning carried out by educators based on information systems. The research objective is to develop an e-lesson plan early childhood education information system that facilitates educators in making learning planning decisions, including educational calendars, semester programs, weekly programs and daily programs. The researcher chose the prototype development model used in this research process. Formative evaluation by users, namely early childhood educators, showed that conformity with the elements of learning tools was $83.3 \%$, and the practicality level of the system was $84.2 \%$. The practicality and suitability of the PAUD e-lesson plan information system affect $73.3 \%$ in the management of planning decision data made by educators. The results of the study show that the PAUD e-lesson plan is practical and suitable for use in making decisions about learning planning tools by educators.
\end{abstract}

Corresponding author: Leni Gonadi

Address: Jalan Batubara No.89 Kel. Purwantoro Kec. Blimbing Kota

Malang Jawa Timur Indonesia Kode Pos 65122

Instansi: Universitas Negeri Malang

E-mail: leni.gonadi.fip@um.ac.id
2021 Universitas Negeri Malang p-ISSN 2406-8780 e-ISSN 2654-7953 


\section{PENDAHULUAN}

Proses pembelajaran pada jenjang pendidikan anak usia dini mencakup beberapa tahapan diantaranya tahapan perencanaan, persiapan, pelaksanaan, proses dan penilaian kegiatan pembelajaran. Perencanaan pengelolaan kelas, pelaksanaan pembelajaran, metode pembelajaran, dan dukungan pada pembelajaran merupakan bagian-bagian dari pengelolaan pembelajaran di pendidikan anak usia dini. Mengawali kegiatan pembelajaran, pendidik sebagai tenaga profesional menyusun rancangan pembelajaran sebagai panduan pelaksanaan kegiatan pembelajaran. Kegiatan penyusunan perencanaan menjadi tanggung jawab pendidik yang memegang peran utama pada rangkaian pelaksanaan pembelajaran (Mulyasa, 2014), (Huda, 2017). Rancangan pembelajaran yang sesuai dengan tahapan pelaksanaan pembelajaran memberikan kemudahan bagi pendidik untuk mengakomodir tujuan pembelajaran dari kurikulum yang diterapkan.

Acuan penerapan penyelenggaraan pembelajaran PAUD di Indonesia yaitu kurikulum 13 PAUD yang mulai berlaku pada Oktober, 2014. Seluruh lembaga diharapkan dapat menjadikan Kurikulum 2013 sebagai acuan kurikulum lembaga dengan tepat (Leksono et al., 2018), dengan tidak menutup kemungkinan untuk memperkaya dengan kurikulum kekhasan daerah dimana lembaga tersebut berada. Tahapan pertama dari rangkaian proses pembelajaran yang mengacu pada kurikulum 2013 PAUD adalah penyusunan perencanaan sebelum mengawali kegiatan pembelajaran. Pelaksanaanya di kota Malang pada pendidikan dasar ditemukan bahwa penyusunan rancangan pembelajaran belum sepenuhnya mengacu pada kurikulum 2013 (Gunawan, 2017), hal ini pada pendidikan anak usia dini di beberapa daerah disebabkan beberapa faktor yaitu kurangnya pemahaman pentingnya menyusun rancangan pembelajaran (Sum \& Taran, 2020), dan kurangnya informasi yang berkaitan dengan kurikulum 13 PAUD (Rahelly, 2018).

Pada dasarnya perencanaan pembelajaran yang disusun membantu pendidik mengorganisasikan pembelajaran yang efisien dan efektif (Richards, Jack C. Lockhart, 1996). Proses penyusunan rancangan pembelajaran menghasilkan dokumen perangkat pembelajaran yang digunakan oleh pendidik sebagai acuan pelaksanaan pembelajaran. Rancangan disusun berdasarkan acuan kurikulum yang disepakati penggunaannya di lembaga PAUD sesuai dengan kebutuhan dan karakteristik lembaga. Kurikulum 13 PAUD menjadi acuan penyusunan perangkat pembelajaran di Kelompok Bermain (KB) - Taman Kanak-kanak (TK) Laboratorium UM. Berdasarkan hasil observasi dan wawancara kegiatan secara teknis penyusunan rancangan pembelajaran yang dilaksanakan oleh pendidik di KB-TK Laboratorium UM yaitu diketik dalam bentuk word dan disimpan dalam Personal Computer (PC) di sekolah, flashdisk ataupun laptop masing-masing pendidik dilanjutkan dengan proses print/cetak sebagai pemenuhan administrasi berbentuk dokumen hardcopy. Beberapa kendala yang dialami oleh pendidik adalah, 1) menginput data kompetensi dan capaian perkembangan yang merupakan bagian dari proses penyusunan rancangan pembelajaran diinput satu persatu sehingga membutuhkan waktu lama; 2) penulisan kode kompetensi yang berulang dan panjang dengan membuka kembali dokumen acuan kurikulum untuk mencocokkan kode kompetensi; 3) perubahan yang terjadi saat pembelajaran tidak terdokumentasikan pada rancangan pembelajaran; 4) perubahan urutan penyusunan tidak dibarengi dengan perubahan dokumen sebelumnya sehingga dokumen penyusunan perencanaan pembelajaran menjadi tidak sinkron. Disimpulkan pengelolaan data perencanaan pembelajaran belum terakomodir secara maksimal maka diperlukan suatu sistem pada perangkat teknologi yang digunakan pendidik untuk memberikan kemudahan bagi pendidik dalam melakukan pengelolaan data pada dokumen perangkat pembelajaran yang telah disusun.

Penelitian ini mencoba memberikan solusi terhadap permasalahan yang disebutkan, yaitu mengembangkan sebuah sistem informasi penyusunan perangkat pembelajaran yang disebut e-lesson plan PAUD yang memenuhi unsur kepraktisan dan kesesuaian. Pengaplikasian sistem informasi pada penyusunan perencanaan pembelajaran di PAUD yang terintegrasi kurikulum membantu mempercepat dan mempermudah penyusunan rancangan pembelajaran di lembaga PAUD (Fitriawati \& Lestari, 2018). Integrasi teknologi dalam pemanfaatannya sebagai sistem manajemen proses pembelajaran dapat membantu administrasi pembelajaran (Jurado et al., 2013), (Shah, 2014). Dokumen persiapan 
148 JINOTEP (Jurnal Inovasi dan Teknologi Pembelajaran) Kajian dan Riset dalam Teknologi Pembelajaran Vol.8, No.2, Juli 202, Hal. 146-156

pembelajaran tersimpan berbentuk file pada sistem, sewaktu-waktu dapat dibuka, dilihat dan diedit kembali. Pemanfaatan teknologi di ranah pendidikan anak usia dini dapat meningkatkan kinerja pendidik dalam integrasi teknologi pada proses pembelajaran (Blackwell et al., 2013). Dapat dikatakan teknologi sistem informasi sudah menjadi bagian dari proses pembelajaran dan memberikan kontribusi positif bagi pendidik baik dalam tahap perencanaan, persiapan, pelaksanaan hingga evaluasi.

Namun, sistem informasi yang ada belum memfasilitasi hal tersebut, sistem informasi pada lembaga PAUD yang telah dikembangkan saat ini lebih mengarah pada proses administrasi keuangan (Fitriani, 2019), pendataan kelas dan akademik (Warni \& Wicaksono, 2015), pengelolaan data (Putri \& Azpar, 2017), serta sistem web media pembelajaran (Maman et al., 2016). Terdapat sistem yang memfasilitasi penyusunan program semester, mingguan dan harian (Fitriawati \& Lestari, 2018) namun belum sesuai dengan unsur-unsur penyusunan perangkat perencanaan pembelajaran di lembaga PAUD yang dapat memfasilitasi pengelolaan data perangkat perencanaan pembelajaran oleh pendidik. Sistem yang dibutuhkan adalah sistem informasi yang dapat mengakomodir penyusunan rancangan pembelajaran sesuai unsur-unsur yang ada pada tahapan penyusunan perangkat pembelajaran sehingga memberi kemudahan bagi pendidik dalam pengelolaan dokumen, penyimpanan dokumen, pemilihan kompetensi, dan model pembelajaran. Sistem yang ada belum dapat menjawab kebutuhan tersebut, sehingga menguatkan peneliti untuk mengkaji susunan perangkat pembelajaran berdasarkan kurikulum Nasional PAUD 2013, mengembangkan sistem informasi penyusunan perangkat perencanaan pembelajaran yang disebut e-lesson plan PAUD dengan menu yang memfasilitasi pendidik dalam menyusun rancangan pembelajaran sesuai acuan kurikulum 2013 PAUD. E-lesson plan PAUD menjadi inovasi penyusunan perencanaan pembelajaran yang memudahkan pendidik dalam proses penyusunan perangkat pembelajaran. Motivasi dan kesiapan pendidik KB-TK Laboratorium UM khususnya dalam bidang teknologi dan visi lembaga yang mengedepankan teknologi informasi dalam meningkatkan mutu proses pembelajaran memberi peluang untuk pemanfaatan sistem informasi sebagai sistem yang menunjang pelaksanaan tahapan perencanaan pembelajaran pada penelitian ini.

\section{METODE}

Model pengembangan prototipe (Pressman, 2005) menjadi acuan proses pengembangan sistem informasi yang disebut $e$ lesson plan PAUD melalui tahapan communication, quick plan, modelling quick design, construction of prototype, development delivery and feedback. Pengembangan prototipe digunakan sesuai tujuan penelitian yaitu mengembangkan e-lesson plan PAUD berdasarkan kebutuhan sistem informasi pengelolaan perencanaan pembelajaran yang akan digunakan oleh KB-TK Laboratorium UM. Model pengembangan prototipe dipilih karena sesuai dengan tujuan penelitian yaitu mengembangkan perangkat lunak untuk pendidikan berdasarkan permintaan dan kebutuhan (Henson \& Knezek, 1991) (Susanto \& Andriana, 2016). Rancangan pengembangan e-lesson plan PAUD melalui 5 (lima) tahap diilustrasikan pada gambar 1 .

Pada tahap komunikasi, peneliti mengamati dan melakukan percakapan dengan kepala sekolah dan pendidik KB-TK Laboratorium UM terkait rutinitas penyusunan perangkat pembelajaran dan apa yang dibutuhkan terkait hal tersebut. Hasil perbincangan menunjukkan adanya kebutuhan sebuah sistem informasi yang mempermudah pendidik dalam pengelolaan data penyusunan perencanaan pembelajaran sebagai salah satu tugas administrasi rangkaian proses pembelajaran. Penyusunan rancangan sebuah sistem dilakukan dengan menyusun sebuah desain tahapan penyusunan perangkat pembela-

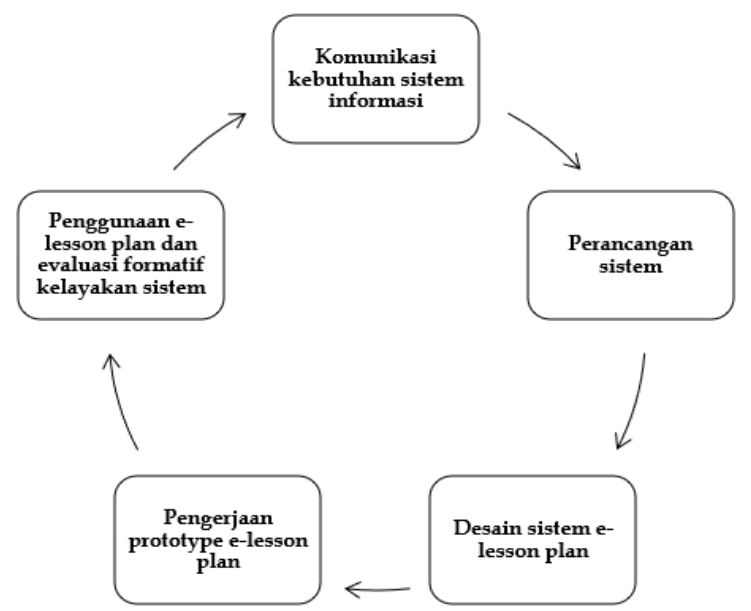

Gambar 1. Alur Pembuatan E-lesson plan PAUD 
-jaran sesuai kurikulum 2013 PAUD yang menjadi acuan keputusan perencanaan dalam proses pembelajaran. Analisis tahapan penyusunan perangkat pembelajaran berdasarkan kurikulum 13 PAUD dengan mengacu pada (Standar Isi Tentang Tingkat Pencapaian Perkembangan Anak, 2014), (Standar Nasional Pendidikan Anak Usia Dini, 2014), kurikulum 2013 PAUD (Kurikulum 2013 PAUD, 2014), (Pedoman Pembelajaran, 2014), dan pengelolaan pembelajaran PAUD (Direktorat Pembinaan Pendidikan Anak Usia, 2015). Analisis dilakukan bersama kepala sekolah dan 10 (sepuluh) pendidik KB-TK Laboratorium UM berdasarkan bagian-bagian yang dianggap penting dalam penyusunan unsurunsur yang terkandung dalam setiap perangkat pembelajaran. Hasil analisis memberikan gambaran dan format desain tahapan penyusunan perangkat pembelajaran dan unsurunsur termuat di dalamnya.

Desain diproyeksikan dalam sebuah alur sistem informasi tahapan penyusunan perangkat perencanaan pembelajaran. Melalui analisis keputusan perencanaan pembelajaran dan diskusi pelaksanaan di KB-TK Laboratorium $\mathrm{UM}$, alur sistem dilanjutkan pada pembuatan sistem informasi yang menghasilkan e-lesson plan PAUD. Pengaplikasian sistem didampingi oleh peneliti untuk mengetahui keterpenuhan pengelolaan data penyusunan rancangan pembelajaran dengan e-lesson plan PAUD.

Evaluasi formatif dilakukan untuk mengetahui persentase kepraktisan, kesesuaian isi dan keterpenuhan aspek pengelolaan data keputusan perencanaan pembelajaran dengan sistem informasi e-lesson plan PAUD dalam penggunaannya pada penyusunan perangkat perencanaan pembelajaran. Instrumen disusun oleh peneliti sesuai kebutuhan pengukuran variabel penelitian pengembangan $e$-lesson plan PAUD pada praktek penyusunan perencanaan pembelajaran. Variabel pada instrumen dalam penelitian ini digunakan untuk memperoleh data mengenai kepraktisan, kesesuaian unsur-unsur penyusunan perangkat perencanaan pembelajaran (Y) dan penggunaan sistem informasi e-lesson anak usia dini (X). Pertanyaan yang disusun sebagai instrumen penelitian menggunakan 4 alternatif jawaban, yaitu sangat setuju, setuju, kurang setuju, tidak setuju. Instrumen yang digunakan oleh peneliti pada tabel 1 .
Tabel 1. Variabel Kepraktisan, Kesesuaian dan Keputusan Perencanaan E-Lesson Plan PAUD

\begin{tabular}{lll}
\hline No & Variabel & Indikator \\
\hline 1 & Kepraktisan & $\begin{array}{l}\text { Tampilan Sistem (Alur } \\
\text { dan Menu Sistem) }\end{array}$ \\
\hline 2 & Kesesuaian & $\begin{array}{l}\text { Unsur-unsur perangkat } \\
\text { pembelajaran anak usia } \\
\text { dini }\end{array}$ \\
& Pengelolaan Data & Keputusan Perencanaan \\
& \\
\hline 3 & 2012) \\
lesson Plan PAUD & Kriteria \\
\hline Rentang Persentase & Tidak Baik \\
\hline $0 \%-35 \%$ & Kurang Baik \\
$36 \%$ - 50\% & Cukup \\
$51 \%$ - 65\% & Baik \\
$66 \%-84 \%$ & Sangat Baik \\
$85 \%$ - 100\% &
\end{tabular}

Instrumen berbentuk kuesioner memuat 20 (dua puluh) pertanyaan tertutup mengukur berapa tingkat kepraktisan, dan kesesuaian unsur-unsur penyusunan rancangan pembelajaran dari sudut pandang pengguna pada sistem informasi e-lesson plan PAUD. Skala likert digunakan untuk menghitung tingkat kepraktisan dan kesesuaian sistem informasi dengan tingkat ideal yaitu $100 \%$ keterpenuhan. Responden merupakan pengguna sistem informasi e-lesson plan PAUD anak usia dini sejumlah 1 (satu) kepala sekolah dan 9 (sembilan) pendidik KB-TK Laboratorium UM.

Uji signifikan dilakukan untuk mengetahui kekuatan hubungan antara variabel kesesuaian yaitu keterpenuhan unsur-unsur perencanaan pembelajaran, kepraktisan sistem informasi e-lesson plan PAUD dengan pengambilan keputusan perencanaan pembelajaran yang dilakukan oleh pendidik. Uji $\mathrm{T}$ dan uji $\mathrm{F}$ dilakukan untuk melihat hubungan antara keterpenuhan unsur-unsur perangkat pembelajaran dan kepraktisan sistem informasi e-lesson plan PAUD terhadap pengambilan keputusan perencanaan oleh pendidik.

Analisis data menggunakan SPSS dilanjutkan untuk menghitung koefisien determinasi, dengan mencari koefisien korelasi antara kepraktisan dan kesesuaian e-lesson plan- 
150 JINOTEP (Jurnal Inovasi dan Teknologi Pembelajaran) Kajian dan Riset dalam Teknologi Pembelajaran Vol.8, No.2, Juli 202, Hal. 146-156

\begin{tabular}{ll}
\hline \multicolumn{1}{c}{ Tabel 3: Tingkat Korelasi Kesesuaian dan } \\
Kepraktisan E-lesson Plan PAUD dan Keputusan \\
Perencanaan (diadaptasi dari (Cohen \& Manion, \\
\multicolumn{1}{c}{ 1994)) } \\
\hline Rentang Korelasi $\left(\mathrm{r}^{2}\right)$ & Interpretasi \\
\hline $0,20-0,35$ & Sedikit berkaitan \\
$0,35-0,65$ & Kurang berkaitan \\
$0,65-0,85$ & Keterkaitan yang kuat \\
$0,85-$ atas & $\begin{array}{l}\text { Sangat memiliki } \\
\text { keterkaitan }\end{array}$ \\
\hline
\end{tabular}

PAUD dan variabel pengambilan keputusan perencanaan. Diharapkan nilai $\mathrm{r}^{2}$ diatas 0,65 menunjukkan adanya hubungan penggunaan sistem informasi e-lesson plan PAUD dengan keputusan perencanaan oleh pendidik.

Sampel diambil sejumlah 30 (tiga puluh) pendidik sebagai perwakilan pengukuran tingkat kesesuaian dan kepraktisan sistem informasi $e$ lesson plan PAUD dalam pengambilan keputusan perencanaan. Jumlah sampel tersebut berdasarkan angka kecukupan minimal dari analisis hubungan/korelasi antara dua variabel (Creswell, 2015). Purposive sampling berasal dari unsur pendidik sebagai pelaksana penyusunan perencanaan pembelajaran sejumlah 30 (tiga puluh) pendidik terdiri dari 16 (enam belas) pendidik perwakilan KB-TK Laboratorium UM dan 14 (empat belas) pendidik dari KB-TK yang ada di kecamatan Lowokwaru yang dipilih berdasarkan kemampuannya dalam penggunaan teknologi dan telah memiliki pengalaman dalam kegiatan penyusunan perangkat pembelajaran minimal 1 (satu) tahun.

\section{HASIL}

Perencanaan pembelajaran yang dilakukan meliputi; 1) menyusun kalender pendidikan, 2) menyusun tema dan sub-sub tema, 3) memilah kompetensi inti, dasar, aspek capaian perkembangan, 4) memilah model pembelajaran, 5) menyusun program semester, 6) menyusun program mingguan, dan 7) menyusun program harian. Teknis penyusunan perencanaan pembelajaran diuraikan sebagai berikut.

Tim pendidik dipimpin oleh kepala sekolah mengadakan pertemuan penyusunan kalender pendidikan yang memuat jadwal kegiatan, diselenggarakan di awal tahun ajaran baru sebelum memulai kegiatan pembelajaran semester. Kalender pendidikan disusun memuat rancangan, yang dibagi dalam dua bagian yaitu semester 1 (satu) dan semester 2 (dua) dengan durasi masing-masing 6 (enam) bulan. Penyusunan kalender pendidikan memperhatikan urutan tema dan subtema pembelajaran, kegiatan didalamya meliputi kegiatan terjadwal berkaitan dengan puncak tema maupun hari besar Nasional. Kegiatan penyusunan kalender pendidikan diikuti dengan pemetaan tema dan subtema persemester pembelajaran. Tema disusun berdasarkan prinsip-prinsip penyusunan tema dan karakteristik lembaga.

Berdasarkan kalender pendidikan yang telah tersusun, dan pemetaan tema dan subtema, kegiatan dilanjutkan dengan perumusan program semester. Unsur-unsur yang ada pada susunan program semester adalah 1) Identitas lembaga, 2) Model Pembelajaran, 3) Alokasi waktu, 4) Kompetensi Inti dan Kompetensi Dasar yang memuat enam aspek capaian perkembangan anak, 5) Tema dan subtema, 6) Rencana Penilaian, 7) Pengesahan berupa tanda tangan pendidik penyusun dan kepala sekolah.

Kegiatan dilanjutkan dengan penyusunan program mingguan yang disusun berdasarkan program semester. Rencana Pelaksanaan Pembelajaran Mingguan (RPPM) memuat unsur-unsur, 1) Identitas lembaga, 2) Kelompok Usia, 3) Tema dan subtema, 4) Model pembelajaran, 5) Waktu pelaksanaan dan alokasi waktu, 6) Kompetensi Inti dan kompetensi dasar, 7) Materi pembelajaran, 8) Rencana Penilaian dan 9) Pengesahan. Program mingguan mencakup rancangan kegiatan selama satu minggu hari aktif sekolah.

RPPM yang telah disusun menjadi acuan pendidik dalam penyusunan program harian yang disebut Rencana Pelaksanaan Pembelajaran Harian (RPPH). Kegiatan penyusunan ini dilakukan setiap hari sebagai acuan pelaksanaan kegiatan pembelajaran harian. Unsur-unsur yang dimuat pada RPPH yaitu, 1) Identitas lembaga, 2) Waktu pelaksanaan, 3) Kelompok usia, 4) Tema dan subtema, 5) Model Pembelajaran, 6) Materi kegiatan, 7) Materi pembiasaan, 8) Alat dan bahan, 9) Teknik penilaian dan rubrik penilaian, 10) Pengesahan berupa tanda tangan pendidik kelas, pendidik pendamping dan mengetahui kepala sekolah. Rangkaian penyusunan perangkat pembelajaran tersebut diilustrasikan pada gambar 2. Berdasarkan susunan tahapan penyusunan perangkat pembelajaran beserta 
unsur-unsur yang tercakup di dalamnya, proses dilanjutkan dengan membuat daftar menu

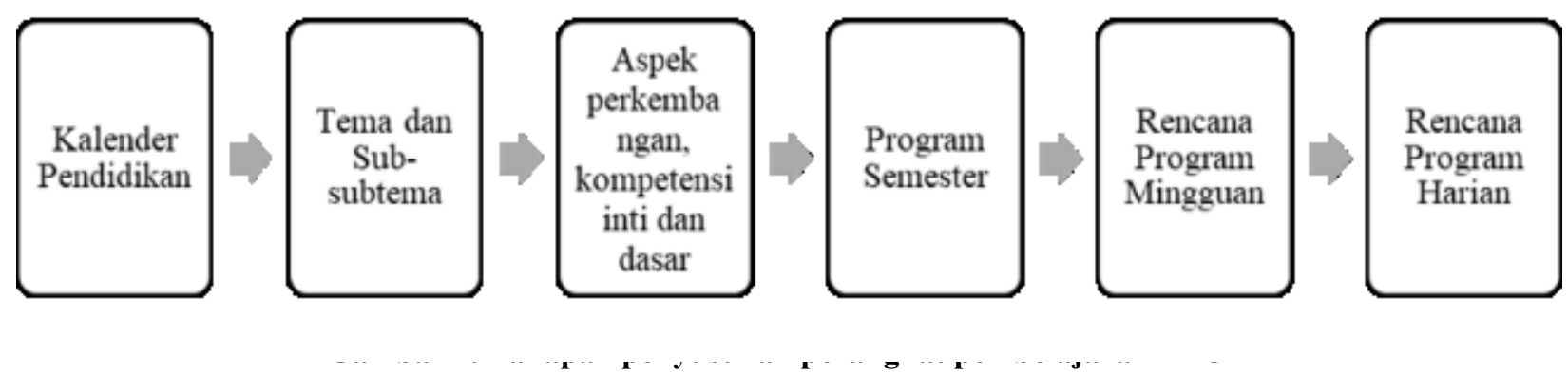

Tabel 4: Menu E-lesson Plan PAUD

\begin{tabular}{cll}
\hline Tahapan & $\begin{array}{l}\text { Komponen keputusan } \\
\text { perencanaan } \\
\text { pembelajaran }\end{array}$ & Menu e-lesson plan PAUD \\
\hline 1 & & $\begin{array}{l}\text { Dashboard, Pengaturan (Kalender Akademik), Download Panduan, } \\
\text { Data Lembaga, Kelompok Usia, Pendidik (data pendidik) }\end{array}$ \\
\hline 2 & Tema \& Subtema & Daftar tema, subtema, sub-sub tema \\
\hline 3 & Kompetensi Inti dan & $\begin{array}{l}\text { Kompetensi (Daftar kompetensi Inti, Daftar Kompetensi Dasar, Daftar } \\
\text { Aspek perkembangan) }\end{array}$ \\
\hline 4 & Dasar & $\begin{array}{l}\text { Model Pembelajaran (Format model pembelajaran kelompok sudut } \\
\text { kegiatan, kelompok kegiatan pengaman, area (minat), dan sentra). }\end{array}$ \\
\hline 5 & Program Semester & $\begin{array}{l}\text { Daftar Program semester (Identitas lembaga, model pembelajaran, } \\
\text { alokasi waktu, kompetensi inti dan dasar, tema dan subtema, rencana } \\
\text { penilaian, pengesahan tanda tangan kepala sekolah dan pendidik } \\
\text { penyusun) }\end{array}$ \\
& & $\begin{array}{l}\text { Daftar program mingguan (Identitas lembaga, kelompok usia, tema } \\
\text { dan subtema, model pembelajaran, waktu pelaksanaan dan alokasi } \\
\text { waktu, kompetensi inti dan dasar, materi pembelajaran, rencana } \\
\text { penilaian dan pengesahan) }\end{array}$ \\
\hline 6 & Program Mingguan & $\begin{array}{l}\text { Daftar program harian (Identitas lembaga, waktu pelaksanaan, } \\
\text { kelompok usia, tema dan subtema, model pembelajaran, materi } \\
\text { kegiatan, materi pembiasaan, alat dan bahan, teknik dan rubrik } \\
\end{array}$ \\
& & penilaian, pengesahan) \\
\hline 7 & Program Harian &
\end{tabular}

Rancangan menu e-lesson plan PAUD diberikan kepada tim pendidik untuk dievaluasi kesesuaiannya berdasarkan hasil diskusi penyusunan perangkat pembelajaran. Hasil evaluasi tim pendidik memberikan masukan penambahan menu data lembaga, kelompok usia, data pendidik dan pelampiran panduan penggunaan sistem informasi e-lesson plan PAUD yang dapat didownload oleh pengguna. Pembuatan sistem dilanjutkan berdasarkan diagram alir sistem informasi e-lesson plan PAUD dan isi menu e-lesson plan PAUD yang telah dievaluasi oleh tim pendidik sebagai calon pengguna sistem.

Prototipe e-lesson plan PAUD dapat diakses melalui laman $\mathrm{http} / / /$ research.eportindonesia.com/ dengan username dan password yang dibagi menjadi tiga pengguna yaitu tenaga admin, kepala sekolah dan pendidik. Pengguna admin memiliki akses lengkap dan dapat mengatur data lembaga dan data pendidik serta mengatur username dan password untuk kepala sekolah dan pendidik.

Pendidik menginput data dalam e-lesson plan PAUD mengikuti urutan unsur-unsur setiap perangkat pembelajaran. Data kompetensi inti dan kompetensi dasar yang terpilah kedalam aspek capaian perkembangan anak secara otomatis dapat diakses oleh pendidik. Perangkat pembelajaran berupa program semester, program mingguan dan program harian pada sistem informasi e-lesson plan PAUD dapat diedit apabila terdapat hal-hal yang memerlukan perubahan dengan memilih menu edit yang tersedia pada setiap menu. Hasil penyusunan perangkat pembelajaran yang telah disetujui oleh kepala sekolah dapat disimpan dalam bentuk $p d f$ atau dicetak dengan memilih menu cetak file 
152 JINOTEP (Jurnal Inovasi dan Teknologi Pembelajaran) Kajian dan Riset dalam Teknologi Pembelajaran Vol.8, No.2, Juli 202, Hal. 146-156

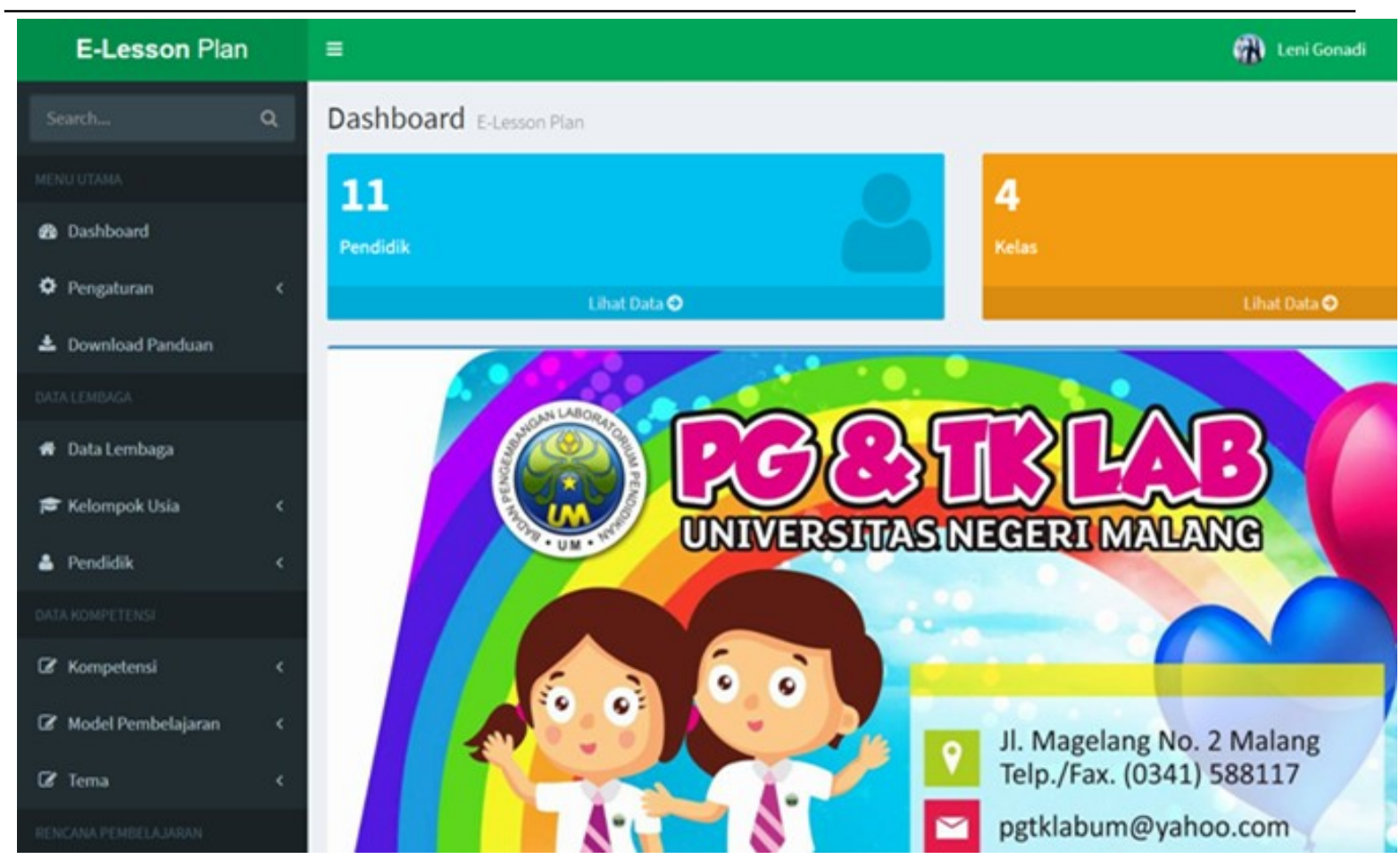

Gambar 5: Dashboard E-lesson plan PAUD

Sistem informasi e-lesson plan PAUD dapat diakses oleh kepala sekolah dan pendidik secara bersamaan dan dimana saja dalam rangka pelaksanaan penyusunan perangkat pembelajaran. Evaluasi kepraktisan dan kesesuaian sistem informasi e-lesson plan PAUD melibatkan 10 (sepuluh) pendidik KBTK Laboratorium UM. Evaluasi formatif terkait variabel kepraktisan dan kesesuain sistem informasi e-lesson plan PAUD oleh pengguna yaitu pendidik anak usia dini, berdasarkan hasil kuesioner yang dibagikan menunjukkan tingkat kesesuaian dengan unsur-unsur perangkat pembelajaran sebesar 83,3\%, tingkat kepraktisan sebesar $84,2 \%$, berdasarkan hasil tersebut sistem informasi e-lesson plan PAUD dinilai praktis dan sesuai dalam penyusunan perangkat pembelajaran.

Uji signifikan dilakukan dengan responden sebanyak 30 (tiga puluh) pendidik KB-TK untuk mengetahui kepraktisan dan kese-

Tabel 5: Efisiensi E-lesson plan PAUD

\begin{tabular}{cccc}
\hline Aspek & $\begin{array}{c}\text { Total } \\
\text { Skor/Skor } \\
\text { Ideal }\end{array}$ & Persentasi & Interpretasi \\
\hline Kesesuaian & $433 / 520$ & $83,3 \%$ & Baik \\
Kepraktisan & $101 / 120$ & $84,2 \%$ & \\
& & & \\
\hline
\end{tabular}

-suaian sistem informasi e-lesson plan PAUD terhadap pengambilan keputusan perencanaan pembelajaran yang dilakukan oleh pendidik. adalah.

Persamaan regresi yang dihasilkan $\mathrm{Y}=1,483+0,159 \mathrm{X}_{1}+0,540 \mathrm{X}_{2}$

Nilai konstanta 1,483 menunjukkan nilai keputusan perencanaan dengan menggunakan sistem informasi e-lesson plan PAUD sebesar 1,483. Jika tidak menggunakan sistem informasi e-lesson plan PAUD maka tingkat keputusan perencanaan pembelajaran adalah sebesar 1,483. Kesesuaian unsur-unsur perencanaan pembelajaran memberikan kontribusi peningkatan sebesar 0,159 pada kegiatan keputusan perencanaan dengan asumsi jika variabel ini meningkat $1 \%$ dan variabel kepraktisan dan konstanta adalah 0 (nol). Hal ini menunjukkan adanya potensi positif dari kesesuaian unsur atau komponen perangkat pembelajaran pada sistem informasi e-lesson plan PAUD anak usia dini bagi pengambilan keputusan perencanaan pembelajaran oleh pendidik. Kepraktisan sistem memberikan kontribusi sebesar 0,540 bagi pengambilan keputusan pembelajaran, dimana jika variabel ini meningkat $1 \%$ dan variabel kesesuaian unsur-unsur perencanaan pembelajaran dan konstanta adalah 0 (nol). Hal ini menunjukkan adanya kontribusi positif dari kepraktisan sistem 
bagi pengambilan keputusan perencanaan pembelajaran oleh pendidik dengan menggunakan sistem informasi.

Hasil uji T pengaruh variabel kesesuaian unsur - unsur perangkat pembelajaran $\left(\mathrm{X}_{1}\right)$ terhadap keputusan perencanaan dengan nilai signifikan $0,043<0,05$, dan nilai $\mathrm{t}_{\text {tabel }}=\mathrm{t}(\alpha / 2 ; \mathrm{n}$ $\mathrm{k}-1=\mathrm{t}(0,05 / 2 ; 30-2-1)=(0,025 ; 27)=2,057$. Berarti nilai $t_{\text {hitung }}$ lebih besar dari $t_{\text {tabel }}(2,126>$ 2,057) menunjukkan adanya pengaruh kesesuaian unsur - unsur dalam perangkat pembelajaran terhadap keputusan perencanaan secara parsial diterima. Hasil uji $\mathrm{T}$ pengaruh variabel kemudahan alur sistem $\left(\mathrm{X}_{2}\right)$ terhadap keputusan perencanaan dengan nilai signifikan $0,037<0,05$, dan nilai $\mathrm{t}_{\text {tabel }}=\mathrm{t}(\alpha / 2 ; \mathrm{n}-\mathrm{k}-1=\mathrm{t}$ $(0,05 / 2 ; 30-2-1)=(0,025 ; 27)=2,057$. Berarti nilai $t_{\text {hitung }}$ lebih besar dari $t_{\text {tabel }}(2,191>2,057)$ menunjukkan adanya pengaruh kepraktisan sistem terhadap keputusan perencanaan secara parsial diterima.

Hasil uji $\mathrm{F}$ terhadap pengaruh simultan efisiensi sistem informasi e-lesson plan PAUD yang meliputi kelengkapan unsur-unusr perangkat pembelajaran dan kemudahan alur sistem terhadap keputusan perencanaan dinilai berpengaruh secara bersamaan apabila nilai signifikan $F_{\text {hitung }}>F_{\text {tabel. }}$ Hasil uji $F$ menunjukkan, nilai $F_{\text {tabel }}=f(k ; n-k), F=(2 ; 30$ $2), \mathrm{F}_{\text {tabel }}=(2 ; 28)=3,34$ dengan tingkat kesalahan $5 \%$. Berarti nilai $F_{\text {hitung }}$ lebih besar dari $\mathrm{F}_{\text {tabel }}(40,715>3,34)$ dan tingkat signifikan 0,000 $<0,05$ menunjukkan efisiensi sistem informasi e-lesson plan PAUD anak usia dini yang meliputi kelengkapan unsur-unsur perangkat pembelajaran dan kemudahan alur sistem secara bersamaan berpengaruh terhadap keputusan perencanaan.

Didapatkan nilai koefisien determinasi sebesar 0,733, menunjukkan variabel efisiensi sistem informasi e-lesson plan PAUD yang meliputi keterpenuhan unsur-unsur perangkat pembelajaran dan kepraktisan alur sistem berpengaruh sebesar $73,3 \%$ dalam pengambilan keputusan perencanaan yang dilakukan oleh pendidik saat menggunakan sistem informasi sebagai alat teknologi informasi pendukung proses pembelajaran, dan sisanya $26,7 \%$ dijelaskan oleh variabel lain yang tidak dicantumkam yaitu efektivitas sistem meliputi kemenarikan tampilan sistem, pertukaran informasi, dan ketepatan hasil sistem dalam sebuah sistem informasi manajemen.

\section{PEMBAHASAN}

Penyusunan perangkat pembelajaran pada penelitian ini mengacu pada pedoman pembelajaran salinan lampiran IV pada (Pedoman Pembelajaran, 2014). Adapun pengelolaan pelaksanaan pembelajaran melalui pendekatan saintifik (Direktorat Pembinaan Pendidikan Anak Usia, 2015). Dasar peraturan yang digunakan yaitu (Standar Nasional Pendidikan Anak Usia Dini, 2014) dan Kurikulum 2013 PAUD (Kurikulum 2013 PAUD, 2014) yang menjadi acuan dasar pelaksanaan kurikulum 2013 di lembagalembaga PAUD Indonesia.

Tujuan akhir stimulasi pembelajaran yang dilaksanakan mengacu pada kompetensi inti dari aspek perkembangan anak (Kurikulum 2013 PAUD, 2014). Kompetensi sikap spiritual, sikap sosial, pengetahuan dan keterampilan yang menjadi kompetensi inti dan dijabarkan masingmasing 2 (dua), 14 (empat belas), 15 (lima belas), dan 15 (lima belas) kompetensi dasar. Pencapaian tujuan melalui pelaksanaan pembelajaran yang terintegrasi 6 (enam) aspek capaian perkembangan anak yaitu; nilai agama moral, fisik motorik, kognitif, bahasa, sosial emosional dan seni. Pilihan 4 (empat) model pembelajaran memberikan kesempatan pada pendidik untuk memilih mengelola kelas sesuai tujuan kompetensi yang diharapkan. Integrasi pendekatan saintifik dilakukan pada setiap tahapan kegiatan perencanaan pembelajaran yang akan memberikan pedoman bagi pendidik dalam pelaksanaan pembelajaran.

Pengambilan keputusan berdasarkan tahapan penyusunan perangkat pembelajaran yang dilakukan oleh pendidik sesuai kurikulum 2013 PAUD dibagi menjadi keputusan perencanaan bersama yang dilakukan bersama oleh kepala sekolah dan pendidik serta keputusan perencanaan individu yang dilakukan sendiri oleh pendidik. Keputusan perencanaan yang dilakukan secara bersama-sama mengidentifikasikan bahwa kegiatan dilaksanakan secara bersama dalam kurun waktu yang sama. Kegiatan merayakan hari besar Nasional seperti Hari Kemerdekaan pada bulan Agustus, hari Kartini pada bulan April dan hari Ibu pada bulan Desember. Aktivitas dilakukan melibatkan seluruh anak, pendidik dan orangtua walimurid. Keputusan secara bersama lebih mudah untuk diterima pelaksanaannya daripada keputusan individu dalam penyusunan perencanaan pembelajaran (König et al., 2020). Keputusan individu dilakukan oleh pendidik 
sebagai profesional yaitu memilih media dan bahan ajar, metode dan model pembelajaran sesuai kondisi kelas yang menjadi tanggung jawabnya.

Pengambilan keputusan dalam tahapan proses pembelajaran adalah hal penting yang dilakukan oleh pendidik sebagai individu profesional yang bertanggung jawab pada jalannya pembelajaran. Terdapat 3 (tiga) pengambilan keputusan yang saling terkait dalam proses pembelajaran yaitu pre active, interactive, dan post active (Westerman, 1991) atau yang disebut keputusan perencanaan, keputusan saat proses pembelajaran berlangsung dan keputusan di akhir proses pembelajaran terkait evaluasi hasil pembelajaran. Pada ranah PAUD, posisi rancangan pembelajaran yang sudah disusun menimbulkan pertanyaan, apakah rancangan tersebut dapat dilaksanakan secara runtut sesuai tahapan yang telah tertulis pada dokumen. Sangat memungkinkaan tujuan pembelajaran akan berubah dalam proses pembelajaran. Perencanaan pembelajaran yang disusun memiliki hubungan yang erat dengan pelaksanaan pembelajaran baik dari strategi, isi kegiatan bermain, dan alat dukung yang digunakan (Ramírez et al., 2017).

Keputusan perencanaan yang dilakukan pendidik dalam menyusun rancangan pembelajaran tidak terlepas dari pemahaman akan karakteristik peserta didik, tujuan pembelajaran, strategi pembelajaran (Milkova, 2005). Pemenuhan akan unsur-unsur yang tercantum dalam perangkat pembelajaran memberikan pengaruh positif bagi pendidik dalam membuat keputusan perencanaan. Pastinya keterampilan dalam mengembangkan pembelajaran yang efektif masih sangat dibutuhkan oleh pendidik (Sahin-Taskin, 2017). Pendidik memilih model pembelajaran sesuai dengan kebutuhan tujuan pembelajaran dan berganti-ganti model pembelajaran. Tahapan pelaksanaan strategi pembelajaran dapat berubah sesuai keadaan kelas, bagaimana menilai rancangan pembelajaran itu baik yaitu saat perencanaan itu berpindah pada pendidik pengganti, maka dapat dimaknai dan dilaksanakan oleh pendidik tersebut (Johnson, 2000) serta pendidik dapat mengubah keputusan perencanaan dalam sistem dan tersimpan sesuai aktivitas pembelajaran yang berlangsung.

Dengan sistem ini, keputusan perencanaan dilakukan melalui tahapan pemilihan tema subtema, aspek perkembangan yang terpilih pada kompetensi inti dan dasar, metode pembelajaran bervariasi, model pembelajaran yang memberikan setting pengelolaan kelas sesuai tujuan pembelajaran dimana pendidik tidak perlu menginput kembali namun langsung memilih dengan mengklik pada menu yang tersedia. Sistem informasi e-lesson plan PAUD memberikan kemudahan alur sistem bagi pendidik untuk mengakses keputusan perencanaan sesuai kebutuhan kelas dengan tema subtema yang dipilih. Kemajuan teknologi informasi memberikan dampak penerapannya pada pendidikan yang memberikan tantangan besar bagi kita untuk memaknai tujuan sistem informasi tersebut dalam keberhasilan pengaplikasiannya (DeLone \& McLean, 2016). Hasil penelitian menunjukkan kesesuaian unsurunsur perangkat pembelajaran dan kepraktisan sistem informasi e-lesson plan PAUD mempengaruhi pengelolaan data yang memudahkan pendidik dalam mengambil keputusan perencanaan yang. Keberhasilan penggunaan TIK di kelas membutuhkan integrasi teknologi dan proses pedagogis yang bijaksana selama persiapan pelajaran (Janssen et al., 2019). Sistem informasi e-lesson plan PAUD menjadi inovasi penyusunan perencanaan pembelajaran yang memudahkan pelaksanaan pengelolaan data penyusunan perangkat pembelajaran pada lembaga PAUD.

\section{SIMPULAN}

Komponen yang ada pada masing-masing perangkat pembelajaran memberikan alur / arah bagi pendidik dalam penentuan keputusan perencanaan. Kepraktisan sistem informasi memberikan kontribusi lebih besar dalam menggunakan sistem informasi sebagai alat bantu untuk pengambilan keputusan perencanaan dibandingkan unsur terpenting yaitu ketepatan isi atau unsur -unsur perangkat pembelajaran. Terdapat kecenderungan memaknai sebuah sistem dari variabel kepraktisan yaitu unsur kemudahan alur sistem dan tampilan sistem sebagai motivasi mereka untuk penggunaan teknologi. Hal ini memberikan tantangan bagi penelitian lebih lanjut tentang bagaimana persepsi pendidik anak usia dini terhadap sistem informasi dalam menunjang rangkaian proses pembelajaran. Berdasarkan komponen kesesuaian unsur-unsur pada sistem informasi $e$-lesson plan PAUD yang 
memberikan alur keputusan perencanaan pembelajaran bagi pendidik, variabel kepraktisan sistem juga mempengaruhi keputusan perencanaan yang dilakukan pendidik dengan menggunakan sistem informasi. Hasil penelitian menunjukkan sistem informasi $e$ lesson plan PAUD praktis dan sesuai sebagai sistem pengolah data penyusunan perangkat pembelajaran oleh pendidik anak usia dini dan memudahkan pendidik dalam membuat keputusan perencanaan.

\section{DAFTAR RUJUKAN}

Blackwell, C. K., Lauricella, A. R., Wartella, E., Robb, M., \& Schomburg, R. (2013). Adoption and use of technology in early education: The interplay of extrinsic barriers and teacher attitudes. Computers and Education, 69, 310 319.

https://doi.org/10.1016/j.compedu.2013.07.02 4

Cohen, L., \& Manion, L. (1994). Research menthods in education (Edisi ke-4). In Research Methods in Education. Routledge.

Creswell, J. (2015). Educational Research Planning, Conducting, and Evaluating Quantitative and Qualitative-Fifth Edition (Fifth). Pearson Education, Inc.

DeLone, W. H., \& McLean, E. R. (2016). Information Systems Success Measurement. Foundations and Trends ${ }^{\circledR}$ in Information Systems, 2(1), 1116. https://doi.org/10.1561/2900000005

Direktorat Pembinaan Pendidikan Anak Usia. (2015). Pedoman Pengelolaan Pembelajaran Pendidikan Anak Usia Dini. Jakarta: Direktorat Jenderal Pendidikan Anak Usia Dini dan Pendidikan Masyarakat. Kementrian Pendidikan dan Kebudayaan.

Fitriani, L. (2019). Perencanaan Sistem Informasi Administrasi di Pendidikan Anak Usia Dini. Jurnal Algoritma, 15(2), 79-83. https://doi.org/10.33364/algoritma/v.15-2.79

Fitriawati, M., \& Lestari, R. H. (2018). Design of the Information System for Kindergarten Learning Plan used Scrum Methodology. IOP Conference Series: Materials Science and Engineering, 407(1). https://doi.org/10.1088/1757899X/407/1/012131

Gunawan, I. (2017). Indonesian Curriculum 2013: Instructional Management, Obstacles Faced by Teachers in Implementation and the Way Forward. 3rd International Conference on Education and Training (ICET). https://doi.org/10.2991/icet-17.2017.9

Henson, K. L., \& Knezek, G. A. (1991). The use of prototyping for educational software development. Journal of Research on
Computing in Education, 24(2), 230-239. https://doi.org/10.1080/08886504.1991.10782 004

Huda, N. (2017). Manajemen Pengembangan Kurikulum. Al-Tanzim: Jurnal Manajemen Pendidikan Islam, 1(2), 52-75. https://doi.org/10.33650/al-tanzim.v1i2.113

Janssen, N., Knoef, M., \& Lazonder, A. W. (2019). Technological and pedagogical support for preservice teachers' lesson planning. In Technology, Pedagogy and Education (Vol. 28, Issue 1, pp. 115-128). https://doi.org/10.1080/1475939X.2019.15695 54

Johnson, A. P. (2000). It's Time for Madeline Hunter to Go: A New Look at Lesson Plan Design. Action in Teacher Education, 22(1), 72-78. https://doi.org/10.1080/01626620.2000.10462 994

Jurado, R. G., Petterson, T., Gomez, A. R., \& Scheja, M. (2013). Classification of the Features in Learning Management Systems. In XVII Scientific Convention on Engineering and Architecture, Havana City, Cuba, Nov 24th-28. XVII Scientific Convention on Engineering and Architecture, 53(9), 1689-1699. https://doi.org/10.1017/CBO9781107415324.0 04

Kurikulum 2013 PAUD, Pub. L. No. Nomor 146 Tahun 2014 (2014).

Standar Isi Tentang Tingkat Pencapaian Perkembangan Anak, Pub. L. No. Nomor 137 Tahun 2014, Peraturan Menteri Pendidikan dan Kebudayaan Republik Indonesia Nomor 137 Tahun 20141 (2014).

König, J., Bremerich-Vos, A., Buchholtz, C., Fladung, I., \& Glutsch, N. (2020). Pre-service teachers' generic and subject-specific lessonplanning skills: On learning adaptive teaching during initial teacher education. European Journal of Teacher Education, 43(2), 131-150. https://doi.org/10.1080/02619768.2019.16791 15

Leksono, F., Sulton, S., \& Susilaningsih. (2018). Implementasi Kurikulum 2013 PAUD Di Tk TPI Nurul Huda Malang. JINOTEP (Jurnal Inovasi Dan Teknologi Pembelajaran) Kajian Dan Riset Dalam Teknologi Pembelajaran, 4(2), $\quad$ 126-131. https://doi.org/https://doi.org/10.17977/um031 v4i22018p126

Maman, U., Sugiarti, Y., \& Ratnawati, S. (2016). Learning system design using knowledge management systems to improve the competency of early childhood education teachers. Proceedings of 2016 4th International Conference on Cyber and IT Service Management, $\quad$ CITSM 2016. https://doi.org/10.1109/CITSM.2016.7577577

Milkova, S. (2005). Strategies for Effective Lesson 
156 JINOTEP (Jurnal Inovasi dan Teknologi Pembelajaran) Kajian dan Riset dalam Teknologi Pembelajaran Vol.8, No.2, Juli 202, Hal. 146-156

Planning Stiliana Milkova Center for Research on Learning and Teaching. In crlt.umich.edu (Issue 2). http://gsi.

Standar Nasional Pendidikan Anak Usia Dini, Pub. L. No. Nomor 137 Tahun 2014, 1 (2014).

Mulyasa, E. (2014). Manajemen Paud. In Manajemen $P A U D$.

Pedoman Pembelajaran, Pub. L. No. Nomor 146 Tahun 2014 (2014).

Pressman, R. S. (2005). Software engineering: a practitioner's approach. Palgrave macmillan.

Putri, N. E., Elizamiharti, E., \& Arman, A. (2021). Sistem Informasi Pendataan Pelanggaran Peraturan Daerah Pada Satuan Polisi Pamong Praja Kota Padang. JOSTECH: Journal of Science and Technology, 1(1), 20-34.

Rahelly, Y. (2018). Implementasi Kurikulum 2013 Pendidikan Anak Usia Dini (Paud) Di Sumatera Selatan. JPUD - Jurnal Pendidikan Usia Dini, 12(2), https://doi.org/10.21009/jpud.122.21

Ramírez, E., Clemente, M., Recamán, A., MartínDomínguez, J., \& Rodríguez, I. (2017). Planning and Doing in Professional Teaching Practice. A Study with Early Childhood Education Teachers Working with ICT (36 years). Early Childhood Education Journal, 45(5), 713-725. https://doi.org/10.1007/s10643-016-0806-x

Richards, J. C., Richards, J. C. R., \& Lockhart, C. (1994). Reflective teaching in second language classrooms. Cambridge university press.

Sahin-Taskin, C. (2017). Exploring Pre-service
Teachers' Perceptions of Lesson Planning in Primary Education. Journal of Education and Practice, 8(12), 57-63. www.iiste.org

Shah, M. (2014). Impact of Management Information Systems (MIS) on School Administration: What the Literature Says. Procedia - Social and Behavioral Sciences, 116, 2799-2804. https://doi.org/10.1016/j.sbspro.2014.01.659

Sugiyono. (2012). Metode Penelitian Kuantitatif, Kualitatif dan R \& D.Bandung:Alfabeta. Metode Penelitian Kuantitatif, Kualitatif Dan $R$ \& D.Bandung:Alfabeta. https://doi.org/10.1017/CBO9781107415324.0 04

Sum, T. A., \& Taran, E. G. M. (2020). Kompetensi Pedagogik Guru PAUD dalam Perencanaan dan Pelaksanaan Pembelajaran. Jurnal Obsesi : Jurnal Pendidikan Anak Usia Dini. https://doi.org/10.31004/obsesi.v4i2.287

Susanto, R., \& Andriana, A. D. (2016). Perbandingan Model Waterfall Dan Prototyping Untuk Pengembangan Sistem Informasi. Majalah Ilmiah UNIKOM, 14(1), 41-46. https://doi.org/10.34010/miu.v14i1.174

Warni, P., \& Wicaksono, S. R. (2015). Rancang Bangun Sistem Informasi Akademik pada PAUD Omah Bocah Annaafi'. Smatika, 05(02), 45-50.

Westerman, D. A. (1991). Expert and Novice Teacher Decision Making. Journal of Teacher Education, 42(4), 292-305. https://doi.org/10.1177/002248719104200407 